\title{
Methods of Teaching the History of Language to Foreign Students
}

\author{
Elena Viktorovna Khabibullina ${ }^{1}$, Ekaterina Gennadievna Shtyrlina ${ }^{1} \&$ Lubomir Guzi $^{2}$ \\ 1Kazan Federal University, Russia \\ ${ }^{2}$ Inštitút rusistiky FF PU v Prešove \\ Correspondence: Elena Viktorovna Khabibullina, Kazan Federal University, Russia. E-mail: elvikh@mail.ru
}

Received: July 17, 2019

Accepted: October 12, 2019

Online Published: October 28, 2019

doi:10.5430/ijhe.v8n7p74

URL: https://doi.org/10.5430/ijhe.v8n7p74

\begin{abstract}
The article discusses the features of methods of teaching the history of language in a foreign language classroom. With regard to the increase of the number of applicants who enroll in Russian universities directly on the basis of secondary education, bypassing the preparatory faculties, which arises the problem of an insufficiently prepared group of learners, in which the disciplines related to the study of the history of the language are taught. Accordingly, the teacher has to solve the problem by revising the methodological approaches to the teaching of the discipline. In particular, it is necessary to vary the volume and content of the educational material, implement the principle of communicativeness in teaching, and use interactive ways to enhance the activities of the students. In fact, the courses become less academic and more oriented towards the practical application of acquired knowledge by the students in order to improve their own knowledge in the field of Russian grammar. We offer our view on the construction of courses "Old Slavonic language" and "Historical grammar of the Russian language" in a foreign audience, methods and ways to ensure the principle of continuity and the actualization of the knowledge gained when studying subsequent courses. The article discusses the types of assignments, by fulfilling which students reinforce their knowledge and skills. The work with foreign students, in the classes of the Old Slavonic language and historical grammar of the Russian language, is focused on creating in the students a positive attitude towards the Russian language and Russian culture.
\end{abstract}

Keywords: methodology, Russian as a foreign language, history of the language, old Slavonic language, historical grammar

\section{Introduction}

In recent years, there has been a steady increase in the number of foreign nationals coming to Russia to study at the undergraduate level in Philology and Linguistics. Whereas previously foreign applicants usually enrolled in Russian universities for humanitarian studies after graduating from preparatory faculties, where they received not only linguistic, but also special training, now more and more often students come to the first year unaware of any philological terminology, and having a vague idea of the place that Russian language has among other languages. Under these conditions, teaching the disciplines that are included in the basic part of the program: "Old Slavonic language" (philology) and "History of the Russian language" (philology, linguistics) is rather difficult. These courses traditionally present complexity and for Russian-speaking students, respectively, the teacher in a foreign audience faces a number of even more serious problems. The purpose of this work is to identify possibilities for improving the teaching of these disciplines to foreign students. In the course of the work, the main features of the construction of the educational process, the presentation of the material, which, in our opinion, will allow this to be achieved, were considered.

\section{Methods}

The research methods were chosen in accordance with the object and material of the research: the analytical - the available textbooks on the history of the language, systematization, pedagogical observation, comparative method, test control method, were analyzed.

\section{Results and Discussion}

In conditions when students who speak Russian language to the extent of the first certification level (B 1) come to the first year, the teacher finds himself in a situation where the students' vocabulary is clearly insufficient for successfully mastering the discipline. One of the ways to overcome the problem is such a distribution of disciplines, according to which the "Old Slavonic language" is studied in the 2nd year, and the "History of the Russian language" - in the third. 
At the same time, such subjects as "Latin language" and "Ancient languages and cultures" remain within the framework of the curriculum of the first course and create the necessary base, allowing students to create general cultural and special knowledge, skills, based on which the teacher is not only unable to realize the principle of integrative learning, but also to create a situation of success and a favorable atmosphere for the students at the beginning of their studies, and partially relieving the tension that is aroused occurs when studying a new subject.

The question that the teacher has to tackle first is the matter of the goals of studying the discipline, since it is this that determines the selection of content. We assume that with reference to the "Old Slavonic language" course attention should be paid to the following: to develop students' understanding of the historical approach to learning a language, acquainting with the principles of the comparative historical method of linguistics and the principles of historical and linguistic commentary of linguistic facts. Taking into account the peculiarities of the trainees, more classroom and extracurricular time should be allocated to the introductory part of the course, which usually presents no particular difficulty for Russian students, - the story of the creation of the first literary language of the Slavs. First of all, it is necessary to form a clear idea among the foreign language classroom regarding the historical and cultural situation at the time of the creation of the Old Slavonic language, about the geography of the event. This is especially the case when it comes to students from China, for whom this information is usually completely new. While dealing with these problems, it is important to apply the principles of clarity and interactivity in conducting classes. Certainly, in order to enhance the attention of the students, a presentation of slides with illustrative material during a lecture by a teacher is needed, the use of this type of visibility has been repeatedly emphasized in the works on teaching Russian as a foreign language. At the practical lesson it is useful to once again demonstrate the same presentation, asking students to comment on the content of the slide, based on the lecture material. It is desirable to include in the presentation material slides containing the terms that are used in the lecture, and their definitions.

It is important to consider the role of the Christian religion in the history of the creation of the Old Slavonic language and to pay attention to the religious content of the handwritten Old Slavonic monuments. Introducing information about the Slavic alphabet, it should be more elucidated how to solve the problem of determining the primacy of the verb in relation to the Cyrillic alphabet, the causes of the emergence of the Cyrillic alphabet and strengthening its positions, the reasons for not using Cyrillic alphabet among a number of Slavic peoples at a later stage of the Slavic languages. In general, the introductory block represents for the teacher the possibility of implementing the communicative principle in teaching, because there is an opportunity to develop students' monologue and dialogical speech skills: a mini-discussion on problematic issues can be held: why Cyrillic was more convenient than the Glagolitic (verb) alphabet, whether or not the extralinguistic factors matter for the development of the Old Slavonic language, etc.

When covering the work of Cyril and Methodius, it must be pursued to cause an emotional response from students, drawing attention to the spiritual feat of the Theuns brothers; it also introduces information on the veneration of Cyril and Methodius, on the traditions of celebrating the Day of Slavic Literature in Russian universities. Since the course is taught in the second semester, it is possible to have this holiday carried out by the students, the program includes reports on the development of Slavic languages, Church Slavonic as the successor of the Old Slavonic language, also it is possible to include interactive forms.

The second block is devoted to the description of graphics and phonetics of the Old Slavonic language: the Glagolitic (verb) alphabet is not discussed in detail in this section, its review is given in the introductory block. Students are invited to study the Cyrillic alphabet - the names of the letters, their sound correspondences, doublet letters. We do not see the need to develop calligraphic writing of letters, as well as memorizing their numerical values - this information is given for familiarization, while the diacritical signs are discussed in more detail. In general, the main task of this section is to develop reading skills in the Old Slavonic language. It is necessary to overcome the difficulties of establishing a connection between the graphic and the sound form of a word on a simpler language material, first reading individual words - while their Russian correspondences should be given in parentheses, the teacher seeks for students to develop an understanding of the lexemes. In the same block, the system of vowels and consonant phonemes of the Old Slavonic language is considered, its differences from the system of phonemes of the modern Russian language, difficulties arise when it comes to fluent syllables, as well as softness of hissing. Here we give a table of the differentiating features of groups of Slavic languages. Note that it is necessary to avoid redundancy of language material, illustrations should be understandable, for example, it is better to take the words нужный / нужда for demonstration of correspondences of the ж/жд, than between the words межа/межда.

The third block is the most important one, the main part of the class hours of the course is assigned to it. It is dedicated to the Proto-Slavic linguistic processes and their reflection in the Old Slavonic language. As practice shows, it is first 
necessary to consolidate knowledge about the transformation of the system of Indo-European vowel phonemes on the pre-Slavic soil. The knowledge test is first conducted in the form of closed-type tasks:

Exercise 1.

Indo-European monophthong * a corresponds to pre-Slavic sound....

$\begin{array}{lll}\text { a) } * \text { б) } *_{0} & \text { в) } *_{\mathrm{e}}\end{array}$

Then in the form of tasks with a short answer, for example:

Exercise 2.

Write the pre-Slavic sound that corresponds to the Indo-European $*_{i}$.

After a certain automatism is achieved, one can proceed to the transformation of archetypes. According to the same principle, the work is based on practical exercises for studying the results of the action of the phonetic laws of the Proto-Slavic language. The main difficulty here is that it is difficult for a teacher to hope for a language guess, moreover, a foreign student, having made an error during the transformation of an archetype, may not see it, because he does not have enough confidence in the Russian language material, it is difficult for him to draw parallels. There are situations when a student makes a mistake, because the archetype is similar to the lexeme existing in Russian: for example, instead of conducting a transformation * *zwonkъ > звжкъ > звук, the student gives as a response*zwonkъ > звонокъ.

In order to minimize errors, it is necessary to form the habit of trainees to comment on each stage of the transformation, explaining the reasons and results of the changes, naming the laws that caused the changes. For this purpose, algorithms are proposed according to which the student will work. The amount of language material that is learned during the course will certainly be less than in the case of working in a Russian-speaking group, but in this case, it provides a better study of the topic. If we talk about the material attracted from other languages, it is desirable to select examples from Latin, German, Slavic languages, in our opinion, it is enough to confine to one or two illustrations from other languages, since the increase negatively affects the attentiveness of students forced to process a significant amount of text.

We focus on those phenomena that allow us to explain the alternations existing in modern Russian. Students studying Russian as a foreign language are usually forced to memorize cases of alternation of vowels and consonants. Our goal is to gain an understanding of the mechanism of their occurrence. We take language material that allows students to consolidate their knowledge in the field of morphemics, word-formation and grammar: the appearance of sizzling in verb forms (пустить - пущу, носить - ношу), in participles (купить - купленный), in adjective forms (тихий тиме, близкий - ближе) еtс..

The fourth block is the grammar of the Old Slavonic language. This block includes all topics that are usually considered in the Russian-speaking audience, but the depth of their study is different. Thus, the topic of the noun is considered in sufficient detail, since the study of the types of declension of nouns, as well as phonetic processes that influenced the re-decomposition of the foundations and the formation of a system of case endings, is very significant in terms of parallels with modern Russian. In the verb system, more attention is paid to the distribution of verbs into classes, phonetic transformations that occurred in verb forms, the paradigm of the present and future tenses of verbs, during the formation of participle forms. The Old Slavonic origin of the participles in the modern Russian language is emphasized, which determined the character of their use in books. The past tense system of the verb is taken for guidance, the formation of a complex past tense is commented on and a parallel is drawn between the Russian past tense and the perfect. A general concept of nominal and term adjectives is given, the difference between the syntactic functions of nominal adjectives in the Old Slavonic language and brief adjectives in the modern Russian language is shown.

The grammar of the Old Slavonic language is studied on the material of small text segments of the Old Slavonic monuments. A commentary on the content of the passage is required, since students from Asian countries lack the cultural competence necessary for understanding it.

Syntactic features of the Old Slavonic language are submitted for optional independent study. In the practical part of the examination ticket, there is no work to translate the passage; the practical task is a commentary on alternation examples.

"The history of the Russian language" is a subject that is read by students of philology after studying the Old Slavonic language, and for linguistic students, it becomes the first and only source of knowledge for historical and linguistic commentary of the facts of the language. 
In the case when the study of the historical grammar of the Russian language is preceded by the course of the Old Slavonic language, the teacher has more opportunities to turn to a deeper consideration of the results of the phonetic Slavonic processes on the Russian soil and show the students exactly the East Slavic (Russian) processes that took place in the sound and grammatical systems of the Old Russian language this is usually done in existing manuals on the subject.

In the second case, part of the information about the first literary language of the Slavs is given in the course "Ancient Languages and Cultures", and the "History of the Russian language" takes on the task of telling about the Slavonic laws of the language, here the method of working and testing students' knowledge is based on the same principle as in the course "Old Slavonic language", but the emphasis is placed on East Slavic reflexes. Regarding the issue of assimilative and dissimilative processes that took place in the Old Russian language after the fall of the reduced ones, we use examples that show how phonetic changes influenced the graphic appearance of a word, for example: тришьды - трижды, сватьба - свадьба.

The section "Historical morphology" does not require students to memorize the contents of grammar tables, since this can be a source of errors for foreigners. It is more important to demonstrate the historical changes that have occurred in the grammar of the Russian language: the loss of the vocative case, the dual number, the simplification of the past tense system and the development of the verb type, the transformation of the ancient Russian participles into adjectives, the development of the category of animation, etc. Practical tasks here are presented in a much smaller volume than in the section "Historical phonetics".

\section{Summary}

Teaching the Old Slavonic language and the historical grammar of the Russian language, built taking into account the peculiarities of a foreign audience, allows the students to work more effectively in the classroom, to apply their knowledge of the irregular features of the modern Russian language system. Since an important component of the courses is historical and cultural commentary, students acquire historical and regional geographic knowledge that allows them to improve their general professional competencies.

\section{Conclusions}

Despite the fact that the courses "Old Slavonic Language" and "Historical Grammar" have a long tradition of teaching in Russian universities, programs and methodological support have been developed, the requirements of the time imply that they can and should be adjusted, if teaching in a foreign language classroom, since the work in a group of students from far abroad does not allow the teacher to rely on the background knowledge available for the Russian students. It is necessary to develop educational and methodological manuals oriented specifically for foreign students, while applying the methods commonly used in the practice of Russian as a foreign language.

\section{Acknowledgements}

The work is performed according to the Russian Government Program of Competitive Growth of Kazan Federal University.

\section{References}

Ardakani, M., Lashkarian, A. \& Sadeghzadeh, M. (2015). The Translatability/Untranslatability of Poetics: Eliot's" Ash Wednesday" and its two Persian translations. UCT Journal of Social Sciences and Humanities Research, 3(1), $52-$ 60.

Barreto, D. M. \& Alturas, B. (2018). Quality-in-use app evaluation: case of a recruitment app for Portuguese SMEs. Quality-in-use app evaluation: case of a recruitment app for Portuguese SMEs, (1).

Bondaletov, V. D., Samsonov, N. G. \& Samsonov, L. N. (2016). Old Slavonic language: Tables. Texts. Educational dictionary. - M.: Flinta, 296

Bochina, T., Ageeva, J. \& Vlasicheva, V. (2014). Multimedia presentation as a strategy of teaching speaking. INTED2014. Proceedings 8th International Technology, Education and Development Conference March 10th-12th, 2014. Valencia, Spain, 7661-7669.

Etcuban, J. O., Campanilla, B. S. \& Horteza, A. D. (2019). The Use of Mathcad in the Achievement of Education Students in Teaching College Algebra in a University. International Electronic Journal of Mathematics Education, 14(2), 341-351. https://doi.org/10.29333/iejme/5718

Kolesov, V. V. (2018). The History of the Russian Language in 2 Hours. Part 2: textbook for undergraduate and graduate programs. M.: Yurayt, 298 
Muyambiri, B. \& Chabaefe, N. N. (2018). The Finance-Growth Nexus in Botswana: A Multivariate Causal Linkage. Dutch Journal of Finance and Management, 2(2), 03.

Miftakhova, A. N. \& Yapparova, V. N. Principles of working with audio-visual materials in course of Russian as a foreign language at the beginning stage of teaching. 12th international technology, education and development conference (INTED), 7122-7128.

Makleeva, E. A., Akhmetzyanova, L. M. \& Yan Zhike, (2018). Integration of teaching methods and principles of selection of language material in classes of Russian as a foreign language. Ad alta-journal of interdisciplinary research, 8(1), 172-174.

Semin, A. N. \& Kurdymov, A. V. (2018). International food security regulation. Opción, 34(85-2), 628-651.

Starikova, G. N. (2017). History of the Russian language. Historical grammar. Study Guide. - M.: Flinta, - 713 c.

Starostina, O. V., Galiulina, I. R. \& Bastrikov, A. V. (2016). Synonymy of endings: Frequency and rarely used forms (from experience of teaching Russian as a foreign language). Journal of Language and Literature, ISSN: 2078-0303, 7(3), 248-251.

Turbin, G. A. \& Shulezhkova, S. G. (2016). Old Slavonic language: Textbook. M.: Flinta, 216 c.

Varlamova, M. Yu., Miftakhova, A. N. \& Bochina, T. G. (2016). Interactivity in teaching a foreign language. Journal of Language and Literature, 7(3), 190-194.

Zakharova, L. A. \& Starikova, G. N. (2012). History of the Russian Language: Historical Grammar. M.: Flinta, Science, 224 